\title{
Preventing Thalasemia: Parents' Awareness of Thalassemia
}

\author{
Mutia Anggraini, Ai Mardhiyah, Aat Sriati \\ Faculty of Nursing, Universitas Padjadjaran \\ Email: mutiaanggraini897@yahoo.com
}

\begin{abstract}
In Indonesia, thalassemia is a major disease which increases its number every year. There were 7,238 patients of thalassemia major in Indonesia in 2016. The highest number was from West Java, 3,039 patients. Thalassemia is preventable. The increasing number of Thalasemia patients impacted the bigger cost of supportive treatment such as blood transfusion, iron chelation for a lifetime, and the cost of treatment when complications occur. In addition, patient and family also should deal with the psychology burdens. This study was to identify parents' awareness of thalassemia towards thalassemia prevention in a public hospital in Bandung. This study applied quantitative descriptive method. It involved 99 parents of thalassemia children. The samples were chosen using the accidental sampling technique. Data were analyzed using descriptive statistic. The data were collected using a modification of Thalassemia Awareness Quesionnaire (TAQ). The results showed that the majority of parents $53(53.4 \%)$ had low awareness of thalassemia, and 47 (46.5\%) of parents had high awareness. Similarly, the majority of parents had low awareness of thalassemia prevention $58(58.5 \%)$, and only $42(41.4 \%)$ of parents had a high category of awareness. Developing of strategy or program to improve the awareness of parents with thalassemia towards thalassemia prevention is needed. Nurses have a role as a provider and educator of thalassemia health information and prevention.
\end{abstract}

Keywords: Awareness, parents, prevention, thalassemia 
Mutia Anggraini : Preventing Thalasemia: Parent's Awareness of Thalasemia

\section{Introduction}

The number of thalassemia patients in Indonesiawas 6,647 peoplein 2014 (Talasemia Foundation Indonesia - Association of Parents of Thalassemia Sufferers, 2014). According to WHO (2014), the incidence of thalassemia carriers in Indonesia was 6 to 10, it means every 100 people there were 6-10 people carriers of thalassemia. West Java province was where the largest number of thalassemia major in Indonesia (Widiyanto 2016).

The child would have few changes because of thalassemia including the child appearance, bone deformities, short of body stature, low self-image, frequent visits to the hospital for transfusion, delayed or absent sexual development, fertility problems and other complications associated with diseases such as heart disease, bone disease, diabetes, infections, etc. (Mazone et al., 2009). Children with thalassemia also feel different from the group, limited in activity, social isolation, low self-esteem, and anxious about the condition of illness and the possible effects of the illness in future (Hockenberry \& Wilson, 2009).

According to Thalassemia International Federation (2013), the first prevention of thalassemia was community awareness and education. Awareness was a key aspect of a person's psychological dimension. Its existence was an overview of understanding, evaluation, and self-knowledge (Dahlan et al. In Riyadi, 2015).

WHO (2008) stated that there were two ways of preventing thalassemia: screening of carrier and prenatal diagnosis. These two programs were expected to become the national program. There were several methods of prevention thalassemia overseas including improving awareness of screening carrier, genetic counseling, prenatal diagnosis during pregnancy, and family planning (Thalassemia International Federation, 2013).

Ghafoor et al.'s (2016) study discovered $60 \%$ of parents were not aware of thalassemia disease, $25 \%$ of whom had little knowledge about the disease and only $15 \%$ of parents understood the complication of thalassemia. He also stated that there was lack of thalassemia prevention because of limited knowledge and low awareness of the community about the prevention of thalassemia.

In Thailand, there were $40 \%$ of the population had abnormalities cell and hemoglobin. The prevention programs were screening of carrier, doing a prenatal diagnosis of a fetus with high risk, and providing choice for parents of a terapheutic abortion for the fetus diagnosed of the thalassemia major (Ratanasiri et al., 2006).

Indonesia has developed a prevention program of thalasemia since 1998. The program includes screening carrier, and genetic counseling. In fact, many burdens occurred related to the implementation of these programs impacted to the increasing of thalassemia patients in Indonesia every year (Wahidiyat, 2010). The diagnostic facilities for thalassemia were limited in Indonesia. (Okan et al., 2009). Lack of accessable information about thalassemia prevention provided for parents was another burden for thalassemia prevention. Thalassemia information was important for Indonesian parents, as most of them only attended elementary school (Khairina, 2013).

The thalassemia prevention program in a public hospital in Bandung includes screening carrier programs, genetic counseling and family planning. The prenatal diagnosis program has not been performed. The prevention programs were socialized more than once every year. Socialization was not only to parents with thalassemia children but also to the foundation of thalassemia parents and several high schools in West Java Province. According to nurses' interview result in a public hospital in Bandung, they stated that seven out of ten parents had their second child after the first child diagnosed with thalassemia. In fact, there were five out seven parents had children with thalassemia more than one.

The awareness of parents with thalassemia children would influence their dicision to prevent pregnancy and having another child suffered thalassemia. The awareness would influence parents' actions. There was a need for a study that determines parents' awareness among thalassemia children about preventing thalassemia. 
Mutia Anggraini : Preventing Thalasemia: Parent's Awareness of Thalasemia

\section{Research Method}

This research was a quantitative descriptive research. The study population was parents of children with thalassemia. The samples were chosen using the accidental sampling technique. There were 99 parents involved in this study. The variable of this research was parent's awareness of thalassemia. Sub-variables in this study includes screening carrier, genetic counseling, prenatal diagnosis, and family planning. Data were collected using questionnaires that contained respondent characteristic data including: gender, age, number of children with thalassemia, relation with children, parent's last education. Data were collected using a modified instrument for thalassemia awareness questionnaire (2010) with Cronbach's alpha value of 0.736 . The collected data then analyzed descriptively by frequency. The high awareness score was valued $\geq 11.37$ and low awareness if score valued $<11.37$. Awareness about prevention if score valued $\geq 10.11$ was high awareness and if score $<10.11$ was low awareness.

\section{Research Results}

Table 1 presents that the majority of respondents were female $\mathrm{n}=75 \quad(75.7 \%)$, more than a half of respondents had a high awareness about thalassemia 39 (52.0\%). $52.1 \%(n=49)$ of respondents aged 26-65 years had low awareness of thalassemia, and 79 respondents had children more than one child. Most respondents had children with thalassemia 1 which was $84(84.8 \%)$ person with low awareness 47 (56.0\%). More than 51 $(51.5 \%)$ of respondents attended elementary school and they had low awareness level 32 $(62.7 \%)$.

Table 2 desribes that $53.4 \%$ of parents of thalassemia had low awareness about thalassemia disease.

Table 3 presents that $58.5 \%$ of parents had low awareness in preventing thalassemia

Table 4 reveals that the majority of respondents had low awareness in carrier screening. It shows that prenatal diagnosis was the type of prevention that had the lowest mean value compared with other types of prevention.

Table 1 Frequency Distribution of Thalassemia Awareness Rates Based on Demographic Data at The hospital X Bandung $2017(\mathrm{n}=99)$

\begin{tabular}{lcccc}
\hline \multirow{2}{*}{ Characteristic } & \multicolumn{2}{c}{ High Awareness } & \multicolumn{2}{c}{ Low Awareness } \\
\cline { 2 - 5 } & $\mathrm{f}$ & $\%$ & $\mathrm{f}$ & $\%$ \\
\hline Gender & 6 & 25.0 & 18 & 75.0 \\
Male & 39 & 52.0 & 36 & 48.0 \\
Female & & & & \\
Age & 0 & 0.0 & 5 & 10.0 \\
18-25 & 45 & 47.9 & 49 & 52.1 \\
$26-65$ & 0 & 0.0 & 0 & 0.0 \\
Above 65 & & & & \\
Number of Children & 6 & 30.0 & 14 & 70.0 \\
1 Child & 39 & 49.4 & 40 & 50.6 \\
More than 1 & & & & \\
Number of Child w/ thalassemia & 37 & 44.0 & 47 & 56.0 \\
1 child & 7 & 53.8 & 6 & 46.2 \\
2 children & 1 & 50.0 & 1 & 50.0 \\
3 children & & & & \\
Child Relation & 7 & 29.2 & 17 & 70.8 \\
Biological father & 38 & 20.7 & 37 & 49.3 \\
Biological mother & & & & \\
Education & & &
\end{tabular}


Mutia Anggraini : Preventing Thalasemia: Parent's Awareness of Thalasemia

\begin{tabular}{lcccc}
\hline Elementary school & 19 & 37.3 & 32 & 62.7 \\
Junior School & 12 & 52.2 & 11 & 47.8 \\
Senior school & 13 & 65.0 & 7 & 35.0 \\
College/University & 1 & 20.0 & 4 & 80.0 \\
\hline
\end{tabular}

Table 2 Level of Awareness of Talasemic Parents at a Public Hospital in Bandung 2017 (n=99)

\begin{tabular}{lcc}
\hline \multicolumn{1}{c}{ Characteristic } & Frequency (f) & Percentage (\%) \\
\hline High Awareness & 46 & 47.5 \\
Low Awareness & 53 & 53.4 \\
\hline
\end{tabular}

Table 3 Parents' Awareness in Preventing Thalassemia at a Public Hospital in Bandung 2017 $(\mathrm{n}=99)$

\begin{tabular}{ccc}
\hline Characteristic & Frequency (f) & Percentage (\%) \\
\hline High Awareness & 41 & 41.4 \\
Low Awareness & 58 & 58.5 \\
\hline
\end{tabular}

Table 4 Parents' Awareness in Preventing of Thalassemia Based on Types of Prevention in a Public Hospital in Bandung 2017 ( $(\mathbf{n}=99)$

\begin{tabular}{clccc}
\hline \multicolumn{2}{c}{ Characteristic } & Mean & Frekuency (f) & Percentage (\%) \\
\hline Screening Carrier & High Awareness & 3.55 & 44 & 44.4 \\
& Low Awareness & & 55 & 55.5 \\
Genetic Counceling & High Awareness & 2.38 & 45 & 45.4 \\
& Low Awareness & & 54 & 54.6 \\
\multirow{3}{*}{ Prenatal diagnostic } & High Awareness & \multirow{2}{*}{1.57} & 45 & 45.4 \\
& Low Awareness & & 54 & 54.6 \\
\multirow{3}{*}{ family planning } & High Awareness & 2.6 & 46 & 46.5 \\
& Low Awareness & & 53 & 53.6 \\
\hline
\end{tabular}

\section{Discussion}

This study discovees that the majority of parents had low awareness about thalassemia disease and the rest had high awareness. The low awareness of thalassemia disease was related to their understanding of the disease, the cause of disease, and signs-symptoms of disease. This study result was in line Ghafoor et al.'s (2016) study who found that the level of parental awareness about thalassemia, at least $60 \%$ of parents were not aware of the cause of major thalassemia in children. This study discovered that parents were not aware that they were the carrier of thalassemia. The impact could be parents being less concerned to thalassemia, as a result they would have another child with thalassemia or carrier of thalassemia. Wong (2009) stated that if both parents were a thalassemia carrier it was predicted that they would have children with thalassemia (25\%), children with a thalsemia carrier $50 \%$, and $25 \%$ chance of thalassemia free.

Awareness is an individual understanding or knowledge about themselves and their existence related to health in their everyday life. They had the desire and were aware of maintaining health for themselves and family (Ginting, 2012). According to Hirnawan (1998 in Safitri, 2008) awareness was a sense of conviction or a state of understanding, it was a sense of knowing something or knowing that it should and was supported by perception or information.

This study revealed that parents had low awareness in doing thalassemia prevention. According to Ghafoor et al. (2016), this awareness affected the inadequate prevention 
Mutia Anggraini : Preventing Thalasemia: Parent's Awareness of Thalasemia

of thalassemia. The study also found that parents had low awareness of the prevention of thalassemia through carrier screening. This in line with research conducted by Moghaddam et al. (2012) that found $78.6 \%$ of parents did not screen for carriers and $71.2 \%$ of parents did not know that they were carriers of thalassemia traits so that their child was born with thalassemia major.

Awareness of parents in preventing thalassemia through genetic counseling was low. This was supported by parents' statement that they did not aware of genetic counseling for thalassemia. Parents did genetic counseling after they had a child with thalassemia major. This finding was in line with Moodi et al.'s (2013) study who found $83.2 \%$ of couples had a very low understanding of genetic counseling, and a small number of couples $(0.8 \%)$ a had good knowledge in genetic counseling.

Parental awareness in preventing thalassemia through the prenatal diagnosis was low. Prenatal diagnosis was a screening test for thalassemia which includes measurement of $\mathrm{MCV} / \mathrm{MCH}$ with or without hemoglobin/prenatal electrophoresis, it was commonly done by CVS or amniocentesis, then followed by DNA analysis. Prevention of thalassemia through prenatal diagnosis decreased the number of newborns with thalassemia (Leung et al., 2008).

Parental awareness in preventing thalassemia via family planning was low. This study showed that parents had less awareness of the importance of family planning. The contraceptives method would prevent pregnancy, and it is also useful for parents who did not know about an abortion program for the fetus less than 6 weeks who has been diagnosed with thalassemia. Haghpanah et al.'s (2013) stated that family planning and the usage of contraceptive is an effective program to prevent the birth of children with thalassemia. Wiradyana (2013) stated that determining gestational age less than 6 weeks for an abortion is quite difficult, because the prenatal diagnosis of thalassemia would be performed after 10 weeks' of gestation. However, when a pregnancy is diagnosed with a major thalassemia and the parents wanted to maintain the fetus, the prenatal diagnosis would be useful for the next reproductive planning.

Moghaddam et al. (2012) stated that the low awareness of people in preventing thalassemia might be due to the knowledge, cost and stigmanization. Khairina's study (2013) discovered that the higher the parent's education then they had a high understanding of thalassemia disease in children, while the lower parental education, their knowledge about thalassemia disease in children was lower. The study found that most parents who attended primary school education had a low awareness of the prevention of thalassemia. The results are in line with Notoatmodjo (2014) that stated the educational level had the influence on health knowledge, especially health behavior. The higher a person's level of education the higher one's awareness and the more mature one's consideration in making a decision.

It is important for nurses to improve parents' awareness of health promotion and illness prevention of thalassemia. Nurses have roles to provide information related to diseases and prevention. The information could deliver to parents via health education as well as evaluation routinely. Health education is effective to improve parents' knowledge and awareness of thalassemia. This is in line Moodi et al.'s (2013) opinion that parents' knowledge increased after health education about the prevention of thalassemia. Increasing parents' knowledge would also increase parents' awareness of thalassemia.

\section{Conclusion}

The majority of parents had low awareness in preventing thalassemia including carrier screening awareness, genetic counseling, prenatal diagnosis and family planning. Parents' low awareness would impact a lack of prevention action of thalassemia, as a result there was a possibility that parents with thalassemia would have another child with thalassemia either thalassemia major or as a thalassemia carrier.

There is a need for developing a routine program of promotion and prevention of thalassemia via health education, screening carrier programs, genetic counseling, and 
Mutia Anggraini : Preventing Thalasemia: Parent's Awareness of Thalasemia

family planning counseling. Further research is needed about the relationship between parents' awareness and prevention behavior of thalassemia.

\section{References}

Ghafoor, M.B., Leghari, M.S., Mustafa, G., \& Naveed, S. (2016). Level of awareness about thalassemia among parents of thalassaemic children. Journal of Rawalpindi Medical College (JRMC), 20(3), 209-211.

Ginting, E. (2012). Strategi komunikasi dan tingkat kesadaran kesehatan (Studi korelasional pengaruh strategi komunikasi tim penggerak PKK pokja IV terhadap tingkat kesadaran masyarakat mengenai kesehatan di Kelurahan Dendang Kecamatan Stabat Kabupaten Langkat). Jurnal Kesehatan, $1-15$.

Haghpanah, S., Johari, S., Parand, S., Bordbar, M.R., \& Karimin, M. (2013). Family planning practices in families with children affected by $\beta$-thalassemia major in Southern Iran. Hemoglobin, 37(1), 74-79. doi: 10.3109/03630269.2012.745419.

Hockenberry, M.L. \& Wilson D. (2009). Wongs's essentials of pediatric nursing $\left(8^{\text {th }}\right.$ Ed.). St. Louis: Saunders Elsevier.

Khairina, D. (2013). Gambaran pendidikan dan informasi terhadap pengetahuan orang tua tentang penyakit thalasemia pada anak di RSUD dr. Zainoel Abidin Centra Thalasemia Banda Aceh. Karya Tulis Ilmiah. Sekolah Tinggi Ilmu Kesehatan U'budiyah Banda Aceh.

Leung, K., Cheong, K.B., Tang, M.H.Y., \& Chan, V. (2008). Prenatal diagnosis of thalassaemia. Continuing Medical Education.
Moghaddam, E.M., Naderi, M., Isadi, S., \& Mashhadi, MA. (2012). Causes of new cases on major thalassemia in Sistan and Balouchistan province in South-East of Iran. Iranian J Publ Health, 41(11),67-71.

Moodi, M., Miri, M.R., \& Sharifirad, G.R. (2013). The effect of instruction on knowledge and attitude of couples attending pre-marriage counseling classes. Journal of Education and Health Promotion, 2. doi: 10.4103/2277-9531.119038.

Notoadmojo. (2014). Pendidikan dan perilaku kesehatan. Jakarta: Rineka Cipta.

Okan, V., Ciligloglu, A., Cifci, S., Yilmaz, M., dan Peh Livan, M. (2009). Red cell indiced and functions differentiating patients with the thalassemia trait from those with iron deficiency anaemia. The journal of International Medical Research, 37(1), 25-30

Ratanasiri, T., Charoenthong, R., Komwilaisak, Y., Fucharoen, S., Wongkham, J., et al.. (2008). Prenatal prevention for severe thalassemia disease at srinagarind hospital. J Med Assoc Thai, 89(Suppll 4), 587-93

Riyadi, A (2015). Pengaruh kesadaran diri dan kematangan beragama terhadap komitmen organisasi karyawan RSUD Tugurejo Semarang. Jurnal Ilmiah Psikologi, 2(1), 102-112.

Wahidiyat (2010). Thalassemia: Permasalahan dan penanganannya. USU respiratory. Repository.usu.ac.id.

Wiradyana. (2013). Skrining dan diagnosa thalassemia dalam kehamilan. Jurnal Obstetri dan Ginekologi. FK Unud Denpasar 